\title{
TÃO PERTO E TÃO LONGE: IDENTIFICANDO E INTERPRETANDO REPRESENTAÇÕES SOCIAIS DO MARAJÓ E DE BELÉM, INFLUENCIADAS PELAS POSIÇÕES LOCACIONAIS E SOCIAIS DOS PERSONAGENS DE DALCÍDIO JURANDIR
}

\author{
Maria Célia Nunes Coelho \\ Professora PPGG/UFRJ \\ Pesquisadora do $\mathrm{CNPq}$ \\ Marcus Vinnicius C. Leite \\ Professor da UNAMA
}

\begin{abstract}
Resumo
Neste artigo analisamos as representações sociais dos interiores - rurais e das cidades e apontamos por identificar e analisar as relações entre as idealizações sociais do Marajó oriental, polarizado por vila/cidade de Cachoeira, e da relativamente distante cidadecapital do estado do Pará (parte da antiga província do Grão Pará), Belém. Tais representações mentais eram, de certa forma influenciadas pelas posições sociais, pelas localizações geográficas (no interior ou na capital) dos indivíduos representados e pelas pretensões de ascensão social dos personagens criados ou recriados nos romances de Dalcídio Jurandir (1909-1979). Nas obras por nós analisadas- Chove nos Campos de Cachoeira (1941), Três Casas e um Rio (1958) e Belém do Grão Pará (1960) - Jurandir retratou o período das primeiras décadas do século XX, pós-boom da economia da borracha, portanto, de relativa decadência que transformou os modos de vida (hábitos e costumes) de seus personagens emblemáticos, habitantes, principalmente, da cidade de Belém, anteriormente embelezada no contexto da Belle-Époque, sob a liderança do intendente municipal, depois Senador Antônio Lemos. A discussão das relações entre história, literatura, sociologia e geografia rural estão presentes, com ênfase dada ao debate sobre as noções de ruralidade e urbanidade, ambas vistas como modos de vida ou ideais de vida. Em suma, discutimos as interpretações de significados/leituras da realidade social influenciadas pelas circunstâncias históricas e geógraficas, bem como, pelo estado de espírito e ambições individuais e coletivas dos seus personagens.
\end{abstract}

\section{Abstract}

This paper examines social representations ofthe countryside - rural and urban - identifying and analyzing the relations between social idealizations of Eastern Marajó, mainly in the village/city of Cachoeira, and the relatively distant capital city of the State of Pará (part of the old province of Grão Pará), Belém. These mental representations, in a way, suffered the influence of the social positions, the geographic locations (in the countryside and in the capital) of the represented individuals, and the social climbing intentions of the characters created or recreated in the novels of Dalcídio Jurandir (1909-1979). In the works analyzed herein - Chove nos Campos de Cachoeira (1941), Três Casas e um Rio (1958), and Belém do Grão Pará (1960) - Jurandir depicted the first decades of the 20th century, after the rubber boom economic cycle. This period was of relative decadence, and transformed the life style (habits and usages) of his emblematic characters and inhabitants, mainly of the city of Belém, a city which had been previously embellished in the context of the BelleÉpoque, under the leadership of Antonio Lemos, the city mayor and afterwards Senator. Discussions about the relations between history, literature, sociology, and rural geography are present in the novel, stressing the notions of rurality and urbanity, both seen as a life style or life ideal. In short, this paper discusses the interpretations of meanings/readings of social reality under the influence of historical and geographical circumstances, as well as the state of mind, and individual and collective ambitions of the characters.

Palavras-chave: Representações Sociais,Marajó, Belém.

Key Words: Social Representations, Marajó, Belém.

\section{INTRODUÇÃO}

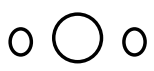

As representações como manifestações de significados possuem papéis cruciais na transmissão de legados históricos e na difusão de conhecimentos entre as novas gerações. As atribuições de significados ou as representações mentais sobre rural e o urbano, o interior e a capital são antiga.

Revista da ANPEGE. v. 3, 2007 
Neste artigo, nosso principal propósito é, ao mesmo tempo, de se opor às tendências anteriores de trastar as diferenças entre o interior, rural e a cidade como "naturais", e explorar estas diferenças a partir do exame da obra de Dalcídio Jurandir, identificando imagens mentais e simbolicas, percebidas e reconhecidas por seus personagens. Boa parte da literatura brasileira trabalhou mais ou menos explicitamente as relações entre representações do rural, do interior e da metópoles e as posições sociais, a busca de ascenção social e econômica dos indivíduos. Além do mais, os indivíduos sempre foram atraídos pela cidade (particularmente, as com status de capital ou metrópole) ou sempre desejaram as coisas que estão nas grandes cidades, ou mesmo sonhavam em reproduzir o modo de vida urbano, independentemente do fato de morarem nas cidades pequenas ou no interior-rural. A literatura brasileira, também, contribuiu muito para ilustrar o fato de que os indivíduos sempre buscaram, em alguns momentos de suas vidas, o ideal de ascensão social ou econômica, tendo a vida na cidade grande como meta.

Com este trabalho pretendemos identificar e analisar algumas representações das paisagens, das sociedades e dos modos de vida do interior — ainda dominantemente rural — relativamente afastado da capital do Pará (representado por Marajó), a cidade de Cachoeira e a cidade relativamente distante de Belém numa época específica - nas primeiras décadas do século XX. Até aproximadamente 1912, Belém tinha sido ainda uma metrópole ("cidade - mãe", Will Bolle, 1994) da Amazônia, uma cidade primaz para onde convergiam os fluxos de indivíduos e da produção via barcos ${ }^{1}$. Belém era a metrópole, por excelência, da bacia amazônica. No momento em que o romancista, por nós analisado, inverteu a posição de seu protagonista, transferindo-o do Marajó para Belém, foi a cidade decadente, que se tornou então o objeto de seu olhar e, conseqüentemente, do nosso também.

Tentamos em nossa análise escapar de uma visão manequeísta, dualista ou bipolarizada — entre o rural e o urbano ou entre o interior e a capital, bem como, dos olhares contratitórios, estereotipados, ao mesmo tempo, românticos ou utópicos de um lugar sobre o outro, trabalhando as noções de ruralidade e de urbanidade vistas como questões de estilos de vida. A urbanidade era um ideal de hábitos e costumes, de formas de comportamento, de autocontrole, ou das maneiras como grupos ou subgrupos de indivíduos se comportavam ou faziam as coisas.

A fonte principal de análise foi parte da produção literária de Dalcídio Jurandir (1909-1979), composta de um total de dez romances, que formaram o "ciclo do Extremo Norte" e foram publicados primeiramente entre as décadas de 1940 e 1970 . Centramos a análise proposta em três romances que se integram numa tensão entre lugares contrastantes representados pelos interiores-rurais, pela cidade de Cachoeira, de um lado, e a cidade-capital Belém, de outro. São eles: Chove nos Campos de Cachoeira (1941), Três Casas e um Rio (1958) e Belém do Grão Pará (1960). Estas obras consistiam em momentos de uma dialética, identificados, em outros trabalhos, como caipira em face da civilização urbana (CÂNDIDO, A. 1964) ou, matutice e civilidade (cf. LEITE, 2002). Este último trabalho é uma análise da obra do escritor paraense oitocentista Inglês de Sousa.

Neste estudo procuramos, sobretudo, entender como o autor selecionado abordou ou representou as paisagens, as constituições societais, as condições e modos de vida no interior-rural e na cidade de Belém. De que maneira o autor e os personagens de seu romances aqui analisados "viam” o Marajó, a vila/cidade de Cahoeira e a cidade de Belém, os outros e si mesmos. Preocupamo-nos em distinguir de onde via ou falava os personagens, bem como, no contexto dos personagens de seus romances quem via e como via, o modo de representar e de entender o mundo dos que viviam ou imaginavam, o Marajó e a cidade de Belém.

Metodologicamente falando, optamos por selecionar e transcrever as passagens (fragmentos de escrita), ou trechos (extraídos de um conjunto) referentes a traços específicos de algumas paisagens e de alguns 
personagens a serem apreciados e interpretados, sem se perder de vista o que identificamos como projeto ou intenções do autor. Em outras palavras, procuramos, então, selecionar e trabalhar os fragmentos de textos que expressavam as representações dos objetos, das paisagens simbólicas e das mentalidades dos personagens emblemáticos e do interior-rural e da cidade, descrevendo o período posterior ao boom da economia da borracha e à Belle-Époque em Belém. Indagamos: Quais eram os sonhos e os olhares de seus personagens para o interior-rural (no caso, o Marajó), para as vilas, posteriormente, cidades vizinhas (CACHOEIRA e MUANÁ) e para a cidade-capital, Belém? Finalmente, optamos por realizar trabalho de interpretação que articulasse análise micrológica dos romances com o seu significado no contexto histórico-social, político e geográfico.

\section{ABORDAGENS MULTIDICIPLINARES}

A aventura de examinar representações que compõem os romances de Dalcídio Jurandir implicou no exame de idéias presentes nas narrativas variadas, dos conceitos-chave diversos do rural, do interior e do urbano, ou ainda, das análises dos contrastes, contemporaneamente, menos evidentes, entre interior rural e cidade. Assim, nossa análise busca incorporar contribuições de várias áreas (geografia, sociologia, literatura, et.) e integrá-las neste texto.

\section{Mitos, Imagens, Ficções e Utopias Sociais}

Perguntamos aqui sobre as representações diferenciadas dos interiores-rurais e das cidades paraenses nas primeiras décadas do século XX, e quais eram as visões que os habitantes dos interiores paraense, aqui representados pelo Marajó oriental, espaço já de havia sido muito desbravado, tinham das paisagens e dos cachoeirenses e belenenses. Estes últimos conviviam com imagens simbólicas, artificializadas pertencentes a projetos de padrão de cidades européias - Paris e Londres - e de indivíduos "civilizados", pessoas "finas" de pequena corte ou da cidade-capital? Nessa direção, partimos da compreensão de que imagem é uma representação mental quase sempre idealizada de algo. E ao entender representação como sendo algo por meio de que se conhece ou que se percebe, consideramos a imagem como uma forma de conhecimento.

Em outras palavras, compreendemos representações como interpretações, como forma de apreensão das coisas e dos indivíduos pelos sentidos, pelos pensamentos ou pela imaginação, muitas vezes, influenciadas pelas circunstâncias geográficas, histórico-políticas e econômicos, bem como, pelos estados de espírito e disposição individual ou coletiva dos indivíduos em mudarem seus destinos. Diferentemente da geografia rural e da sociologia rural tradicionais buscamos por meio das representações apreender realidades sociais, entender diferenciações e diversidades de representações encontradas nas fontes alternativas como os romances.

Mito, por sua vez, é uma imagem tomada como verdade apresentada com coerência e resolução. As interpretações se formaram a partir do confronto das imagens mentais da figura do citadino com os mitos "modernistas", (re) inventados e difundidos. Reproduzidos nos contextos históricos e geográficos diversos, estes mitos são recorrentemente evocados tanto pelos estranhos à realidade interiorana ou rural, quanto pelos habitantes locais, que individual ou coletivamente, de maneira ampla, os interiorizaram como verdades inelutáveis.

No mundo da literatura, além de imagens e mitos, as ficções sociais dos textos são compostas de estórias passadas e quase sempre lendárias e distorcidas de histórias orais, várias vezes recontadas, de recordações do passado, de convenções, de estereótipos socialmente criados ou recriados e naturalizados, 
ou podem simplesmente emergir das mentes criativas dos escritores. Assim, podemos afirmar que os produtores de literatura neo-realista (mas não só eles) no processo de construção de realidades ficcionais e de conferência de sentidos e ordenamentos do real, se apropriam dos mundos interioranos e citadinos, ou rurais e urbanos, objetos de atividades de atribuição de significados, expressos em categorias mentais (mitos, imagens, convenções sociais e estereótipos) percebidas ou identificadas e por eles reproduzidas, por meio de personagens (re)inventados.

Identificar visões, imagens e mitos significa também se deparar com utopias sociais que acompanharam o processo "modernizador" que marcou a sociedade regional em uma dada época, e que teve como conseqüências sociais, certamente, a consagração de hierarquias sociais, espaciais e a manutenção de desigualdades sociais nelas enraizadas.

\section{O Campo (o interior-rural) e a Cidade na História das Sociedades Humanas}

Raymond Williams (1990), famoso marxista inglês, iniciou o seu livro O Campo e a Cidade discutindo para a história das sociedades humanas o que representam as palavras "campo" (aqui por "interior-rural") e "cidade". As primeiras estão vinculadas à extração de recursos naturais e à luta pela sobrevivência cotidiana. A segunda é o espaço das realizações: de saber, das comunicações, da energia, etc. Ao interior-rural ou campo, nas palavras do autor, estavam associados valores como: paz, inocência, simplicidade, virtude etc. Contudo, agregavam-se e estas palavras, valores negativos, sustentava Williams (1990, p. 11), pois o interior dominante rural é quase sempre visto como lugar de atraso, ignorância e limitação e simplificação enquanto a cidade é considerada como um lugar de barulho, mundanidade, modernidade, socialização e ambição. A materialização destes valores em imagens está associada às transformações decisivas nas relações entre campo e cidade que ocorreram na Inglaterra muito cedo, num grau acentuado, e que não encontram - sobre certos aspectos - paralelo na história mundial (WILLIAMS, 1990). A literatura era uma ótima "fonte" para investigar as mudanças de valores decorrentes destas transformações, mas não buscando a veracidade histórica, e sim a perspectiva histórica - sustenta o crítico marxista (1990, p.23). Em outras palavras, descrevê-la e analisá-la a partir de sua conexão com a experiência histórica da qual emergiu ou surgiu.

Williams (1990, p.69), no decorrer de seu estudo, nos esclareceu melhores sobre o contraste entre o rural (campo, na expressão do autor) e cidade. A idéia de uma "inocência rural", muito presente na literatura rural inglesa, tinha sua chave interpretativa na oposição entre, "de um lado, o campo [rural] e, de outro, a cidade e a corte". Quer dizer, natureza versus mundanidade. Contudo, este contraste é retórico, isto é, "uma separação ideológica" (WILLIAMS, 1990, p. 69). Reportandose às causas socioeconômicas do crescimento das cidades pós-medievo, Williams (1990, p. 71) argumentava que a maioria das cidades se desenvolveu como um aspecto da ordem agrícola, seja como mercados, seja como centros de finanças, administração e produção secundária. As cidades, entre elas a capital, estavam funcionalmente ligadas às unidades de áreas produtivas e à importação da produção do rural para os mercados urbanos. Por isso, ao vermos as contraposições entre virtude rural e ganância urbana, não podemos nos esquecer da existência dos "vínculos regulares, necessários e funcionais entre as ordens sociais e morais que eram contrastadas", constatava Williams (1990, p.72). Dito de outro modo, a imagem da cidade como lugar de perversão era ideologicamente criada e difundida pela classe dos donos da terra rural, que não querem perder força-de-trabalho para ela, a cidade. Destarte, a literatura rural possuía um caráter fetichista: "promover comparações superficiais e impedir comparações reais" (WILLIAMS, 1990, p.79).

Entretanto, no segundo quartel dos setecentos, o mundo rural sofreu um decisivo revés das forças capitalistas ligadas ao capital mercantil. Este revés se originou da campanha de cerceamento das terras 
comunais promovida pelo Parlamento que levou a um reordenamento dos valores, na medida em que a classe dominante rural deixava de ver em sua propriedade uma herança que gerava uma determinada renda, para vê-la como uma oportunidade de investimento. Esta nova situação foi classificada de "ideologia do melhoramento", principalmente de organização da terra (Williams, 1990, p.89). Por conseguinte, no final do século XVIII a sociedade inglesa já se encontrava totalmente subordinada a uma ordem capitalista. A literatura não ficava insensível aos processos sociais e às mudanças de valores. Era e é na forma romanesca uma das maneiras de se expressar melhor esta nova situação, na medida em que melhor apresenta os temas de amor e de matrimônio; questão de grande importância para uma sociedade dominada pela propriedade fundiária.

\section{O Mundo Rural e Urbano no Campo da Sociologia e da Geografia Rural}

A Sociologia Rural teve no Brasil o seu ponto de partida na (des)construção das imagens e dos mitos fundamentados nas idéias dos visitantes estrangeiros e da elite ${ }^{2}$ urbana brasileira acerca do exotismo da paisagem rural ou interiorana, do primitivismo ou rusticidade do Novo Mundo ou do sertão [interior] brasileiro, da vida do "caipira" e do arcaísmo da vida rural, em oposição à vida urbana moderna do litoral, das cidades litorâneas (QUEIROZ, 1979). Mesmo nos países de capitalismo avançado, a vida interiorana rural continuava a ser caracterizada como conservadora, resistente às inovações. A desvalorização deste modo de vida rural, em face da Revolução Industrial, instaurou um novo modus vivendi nas cidades, subordinando a produção rural ao seu interesse. Portanto, a Sociologia Rural nestes países surgiu para estudar a crise nos grupos ou subgrupos sociais que vivem no meio rural, que sofrem com a urbanização do meio rural, conforme Maria Isaura Pereira de Queiroz (1978).

O processo de urbanização brasileira no século XIX não estava ligado "intimamente à industrialização, e sim à difusão cultural de um gênero de vida, o gênero de vida burguês ocidental que é eminentemente citadino" (QUEIROZ, 1979, p.168). As cidades brasileiras, que se enriqueceram com a exportação de produtos tropicais (café no Sudeste e látex no Norte), passaram a consumir bens e serviços e a adotar costumes e hábitos provenientes dos centros europeus (Londres, Paris e Lisboa), buscando se inserir no círculo da civilização européia. A ligação estreita da economia citadina no Brasil à produção da riqueza no meio rural gera uma dependência da cidade em relação ao meio rural e, quando a produção declina, verifica-se uma aproximação da vida social entre os dois elementos (o urbano e o campo), atesta Queiroz (1979).

Para a Geografia, as cidades, sedes dos municípios, eram e são aglomerações populacionais, centros com funções múltiplas (político-administrativo, comercial, portuária, industrial, de serviços e cultural) e superpostas, resultantes de uma história complexa e de desenvolvimento quase nunca linear, que as diferenciaram das áreas de ocupação extrativista, agrícola e pastoril ou de características populacionais dominantemente dispersas. A dualidade sobre a qual repousaram a Geografia Rural e a Geografia Urbana brasileira no passado encontrava-se ainda confirmada nas abordagens pouco dinâmicas dos contrastes que, no entanto, são cada vez mais aparentes entre os interiores-rurais, as cidades interioranas e as cidades-capitais. Em suma, a Geografia do passado trabalhava a cidade como um locus de aglomerações populacionais e de concentrações das atividades secundárias e terciárias (comércio e serviços) e o rural como áreas geográficas das dispersões populacionais, das atividades primárias (extrativistas ou agropecuristas), ressaltando, portanto, os tradicionais contrastes entre o rural e o urbano. Isto reforçava a leitura reducionista do rural como "atrasado" ou "tradicional" e no urbano como o novo, o complexo, parte do mundo moderno. 
O geógrafo Max Derruau (versão 1973) assim resumiu as relações entre campo (rural, relativamente, lento e atrasado) e cidade dinâmica (relativamente rápida em receber e adotar inovações):

As relações cidade-campo são simultaneamente residenciais, alimentares, intelectuais, psicológicas e sociais. No total, é um papel dirigente aquele que as cidades exercem em relação ao campo. Exceto em país nômade, o governo encontra-se na cidade, aí se concentra a riqueza e a vida intelectual é mais ativa. É da cidade que provêm as inovações. [...] A cidade cria um modo de vida dos quais muitos elementos são em seguida imitados com atraso maior ou menor, pelo campo. Por razões econômicas e psicológicas, o rural segue com atraso a inovação do citadino, considerada simultaneamente como invejável, um pouco perigosa e, em todos os casos, feita para uma população nitidamente diferente. Mas com o tempo adapta também esta moda ou aquela técnica (DERRUAU, 1973, p. 253-254).

Velhas e novas formas de ocupação humana eram possíveis de serem combinadas no meio rural e na cidade. A cidade sob impacto do capitalismo tornou-se social e espacialmente desigual, guardando bolsões internos de miséria ou pauperismo, porém, os modos de vida urbanos permanecem valorizados em detrimento do estilo de vida rural. Para os geógrafos brasileiros contemporâneos, no entanto, com o desenvolvimento dos transportes, das comunicações e da informática, as relações entre o rural e o urbano ou o interior e a cidade tornaram-se cada vez mais dinâmicas e complexas; os modos de vida da cidade chegam com maior rapidez ao rural. Houve revitalização dos meios rurais. Os meios rurais e os urbanos interagem, reduzindo as distâncias que outrora ampliavam os velhos contrastes; mas o grau de acessibilidade, a posição, a ausência/presença de interações em rede entre lugares e os graus de articulações entre

escalas locais e globais permanecem sendo importantes fatores para explicar tanto os dinamismos quanto os problemas urbanos ou rurais (SPÓSITO, M. E. B. e WHITACKER, A. M., 2006).

Em síntese, a questão do que eram ou o que são os interiores, o rural ${ }^{3}$, ou os rurais (as retaguardas das grandes aglomerações populacionais e dos grandes mercados ou simplesmente dos espaços das cidades), e do que eram ou são o urbano ou as cidades foi mais clara no passado do que tem sido no presente. As contradições nas formas de utilização da terra e nos estilos de vida social (condutas, hábitos e costumes cotidianos) dos espaços - rurais e urbanos ou interiores-rurais, cidades interioranas e cidades-capitais - foram reduzidas com a expansão das periferias das grandes cidades, com a ampliação dos meios de comunicação e a conseqüente diminuição das distâncias relativas, ou ainda com a revitalização recente de localidades rurais sustentadas em atividades tidas como urbanas e com a valorização da "natureza" ainda primitiva (no sentido de pouco transformada ou não integralmente artificializada pelos seres humanos) e como paisagem de contemplação, pelo turismo.

As imagens bucólicas da natureza "natural" ainda não inteiramente "domada" (ecossistema, objeto de descrição, preservação e de contemplação) e as idéias românticas do interior rústico dominantemente rural, de um lado, as imagens construídas (repletas de significados e de simbolismos) cotidianamente e as visões idealizadas das cidades (principalmente das capitais), de outro, sempre predominaram na literatura que retratou a ruralidade (usada até então em oposição à urbanidade) do Brasil até a primeira metade do século XX.

\section{As Noções de Interior e de Ruralidade ${ }^{4}$}

O interior era e é quase sempre visto como a retaguarda da "civilização" e dos centros comerciais, político-administrativos e financeiros. De um lado, há o sertão que é ainda tido como o espaço rústico, selvagem, as subunidades espaciais ainda não integradas à "civilização" ou ainda nãocivilizadas; de outro, o sertão pode ser visto como a retarguarda depreciada ou decadente, pouco dinâmica que abas- 
tecia e abastece precariamente a cidade de alguns produtos do estrativismo ou da agropecuária pouco desenvolvidos. De acordo com esta última visão, sertão podia ou pode conter pequenos núcleos (vilas, povoados) cujos habitantes estavam ou estão marcados por forte ruralidade. Sua população ou uma camada de sua população era ou é dotada de mobilidade, do ir e vir da cidade para o meio rural (e vice e versa). Estes dois sentidos do termo sertão guardam em comum certo distanciamento da cidade e guardam o sentimento de pertencer a um outro espaço distinto da cidade grande, desprovido de oportunidades de ascenção social, o que é comum considerando tanto a rigidez das sociedades nos centros de poder, sede da "pequena corte", quanto das sociedades urbanas, ainda que decadentes.

A noção de ruralidade esteve mais marcante no passado do que no presente e era associada às noções de sociabilidade relativamente escassa, convivência distante, identidade com a terra, valores pouco civilizados, posturas, hábitos e costumes tradicionais associados ao mundo rural, o que era visto como natural quando confrontado ao mundo urbano. A idéia do Jeca Tatu, o mito criado pelo Monteiro Lobato, estava vinculada à simplicidade primitiva e ingênua (no cinema representado pela figura do personagem Mazaroppi), ao estilo rudimentar de vida rural, ou seja, à caipirice dos habitantes do meio rural. A ruralidade era, em geral, vista como sentimento de isolamento, retraimento, constrangimento, melancolia em oposição a visão da urbanidade, ou seja, da cidade como local de orgulho, de valores, de hábitos e de sociabilidade ou de convivências "civilizadas". Porém, com as expectativas de modernidade, estendida ao interior, a visão de rural passou a ser amplamente reformulada. A associação entre interior ou rural com atraso passou a ser rejeitada e amplamente combatida.

Maria José Carneiro (1998) compreendeu a ruralidade como uma representação social. Para a autora a "ruralidade não é mais definida com base na oposição à urbanidade. O rural e o urbano corresponderiam, portanto, a representações sociais sujeitas a reelaborações e ressemantizações diversas de acordo com o universo simbólico a que estão referidas" (CARNEIRO, 1998, p.73).

Acreditamos que a urbanidade pode vincular-se também aos estados de espírito, à disposição ou à ambição dos indivíduos de mudar seus destinos sociais e seus status econômico. A urbanidade, assim, está associada às visões idealizadas das cidades não só como centro de poder, mas também de civilização, de auto-controle, ou seja, de uma "sociedade de corte" (NORBERT ELIAS, 2001) e de novas oportunidades de mudar o destino social. Nas cidades onde os indivíduos se esbarram a todo tempo, bem mais do que no campo, o distanciamento físico-espacial é menor. Este autor, Norbert Elias, demostrou que as idéias de auto-controle, "de controle dos afetos" estavam entrelaçadas às idéias de civilidade e de sociedade de corte.

\section{A Corte e a Idéia de Urbanidade}

Recorremos aqui, portanto, a Nobert Elias (2001) que trabalhou a corte real do Ancien Régime, porém seu objeto de pesquisa eram as formas sociais de figurações sociais construídas por indivíduos, como a sociedade feudal ou a cidade. Para Roger Chartier, que escreveu o prefácio à versão brasileira do livro Sociedade de Corte de Norbert Elias, o objeto de seu livro era:

Não se trata para ele de apreender apenas, ou prioritariamente, a corte como lugar ostentatório de uma vida coletiva, ritualizada pela etiqueta, inscrita no fausto monárquico. O objeto do livro é a sociedade de corte — no duplo sentido do termo. Por um lado, a corte deve ser considerada como uma sociedade, isto é, uma formação social na qual são definidas de maneira específica as relações existentes entre os sujeitos sociais e em que as dependências recíprocas que ligam os indivíduos uns aos outros engendram códigos e comportamentos originais. Por outro lado, a sociedade de corte deve ser entendida no sentido de sociedade dotada de uma corte (real ou principesca) e inteiramente organizada a partir dela. 
Para Elias (2001, p. 62):

Dentro de cada campo social, existem órgãos mais representativos e outros menos representativos, órgãos centrais e outros menos centrais. A cidade, por exemplo, sobretudo a grande cidade, é um dos órgãos mais representativos de nossa sociedade. Em nosso campo social, ela é a matriz que tem, de longe, o efeito mais abrangente. Suas consequências e influências não podem ser evitadas nem mesmo pelos habitantes dos campos na periferia, apesar de toda resistência. O tipo humano determinante, exemplar, mais influente de nossa sociedade vem da cidade, ou pelo menos é marcada pela matriz urbana. Neste sentido, os homens da cidade são representativos para nossa sociedade.

A ruralidade e a urbanidade são agora, mais do que nunca. questões de ideais de mentalidades, de regras de convivências, de posturas, de hábitos, de costumes e de convenções. Os estereótipos ou ficções sociais desenvolvidos no cotidiano, são certamente, associados ao modo ou estilo de vida influenciados respectivamente por condições materiais e imateriais de existência no interior-rural ou no espaço urbano e também pelas inserções de cada um no mundo globalizado. O sentimento ou comportamento concernente à ruralidade, todavia, pode estar presente, mesmo, na mentalidade mesmo e nas formas de convivências, comportamentos normatizados e de consumo cotidianos dos habitantes tanto do interior quanto das cidades de portes diversos.

\section{O ROMANCISTA, OS LUGARES E AS SOCIEDADES RETRATADAS}

O romance é comumente visto como uma representação no plano literário da vida cotidiana em sociedade. Ser romancista muitas vezes implica em ter mémoria (faculdade de lembrar). Sobre romances anamnésicos escreveu Roland Barthes:

com razões ou não (quero dizer: sob pena de exame e de reviravolta eventual), romances que amo = romances da Memória = feitos com materiais ("lembranças") evocados da infância, da vida do sujeito que escreve. Proust fez disso a teoria de sua obra ... (BARTHES, 2005 -edição brasileira-,pp. 31-31)

Ser um romancista regionalista demanda, certamente, um saber regional, e saberes relativos aos espaços vividos, aos lugares, conhecimentos e percepções sobre a sociedade. A cidade-capital tende a ser um centro regional privilegiado como lugar das trocas econômicas e, particularmente, culturais, pois os cidadãos na cidade se relacionam de forma mais estreita, mais cotidiana e, portanto, contínua. Para a Milton Santos (2000), "os lugares são, pois o mundo, que eles reproduzem de modos específicos, individuais, diversoos" (SANTOS, 2000, p. 112). Ainda para ele, "lugar é o espaço vivido, de experiência sempre renovada, o que permite, ao mesmo tempo, a reavaliação das heranças e a indagação sobre o presente e o futuro" (SANTOS, M. 2000, p. 114). Conforme Barthes (versão 2005), a abordagem metafórica do lugar é mais significativa do que sua definição abstrata, (BARTHES, 2005, p. 66). O que Barthes denomina romance é um narrativa fantasiosa que não pode ser assumida como uma história real ou como uma metalinguagem (científica, histórica ou sociológica) (BARTHES, versão 2005).

\section{De Onde Falava e Sobre o Que Escrevia Dalcídio?}

O tempo e o espaço constituem dimensões diferenciadas de toda existência humana e de todas as situações ou experiências vividas. O autor Dalcídio Jurandir nasceu no Marajó. Era, sem dúvida, um escritor geograficamente enraizado. Em suas obras, Dalcídio ora elegeu a ruralidade ora a urbanidade ou as relações entre elas como objetos de sua percepção. Os fios condutores pareceram ser os contrastes ou as singularidades da cidade de Belém e de Marajó, as relações entre a cidade-capital e o interior e 
as mentalidades (as sensibilidades, os costumes e os hábitos), ou seja, as ambições de ascender na vida social, as maneiras de sentir, de pensar e agir de uma época específica marcada por visões particulares de mundo dos indivíduos que compõem as sociedades desiguais pós-escravistas, vinculadas a tempos e a espaços específicos. Concordamos com Rosa Acevedo (2006), para quem o texto de Dalcídio Jurandir pode ser visto como "narrativa literária que está enraizada ou se nutre de uma experiência histórica, por entender que momentos da narrativa apreendem-se à sociedade paraense próxima de formas e relações escravistas, de subordinação a poderes constituídos. Mas a narrativa literária não é, nem pretende ser história" (ACEVEDO, 2006, p. 93).

O protagonista, Alfredo, era um menino que vivia em um estado de liminaridade. Ele era filho do Major Alberto, branco e secretário da Intendência e da negra Dona Amélia. Sentia-se fora do mundo de Cachoeira. Ele "achava esquisito que seu pai fosse branco e sua mãe preta" - comentou o narrador (JURANDIR, 1998, Chove nos Campos de Cachoeira, p. 121). Contudo, era desagradável ser chamado de "branco" pelo moleque Henrique, este fazia parte dos "meninos rotos e febrentos" (JURANDIR, 1998, Chove nos Campos de Cachoeira, p. 312), que julgava "tão natural que Alfredo parecesse branco. Não mora num chalé de madeira, assoalhado e alto? Era filho do Major Alberto, tinha sapatos" (JURANDIR, 1998, Chove nos Campos de Cachoeira p. 121).

O autor escreveu sobre vidas no Marajó e em Belém, assim, o menino Alfredo percebia tudo com um misto de ingenuidade infantil e de complexidade, de inquirições ora emocionais ora intelectuais, acerca dos distanciamentos entre a cidade de Belém e Cachoeira no Marajó, e dos contrastes entre ricos/ coronéis e pobres/oprimidos, comerciantes de Belém e taberneiros do Marajó , entre donos da terra e "camponeses"/pequenos produtores familiares, ribeirinhos ou não, com ou sem terra, entre brancos, pretos e mestiços, entre casados, solteiros, velhos, moços e crianças, entre canoeiros, pescadores, costureiras e prostitutas, entre funcionários públicos, comerciantes, profissionais liberais, trabalhadores rurais (vaqueiros) e ociosos (tios - bimbas) $)^{5}$, etc.

Para nós, o projeto do escritor neo-realista, Dalcídio Jurandir, consistia, basicamente, de reconstituir criativamente do ponto de vista literário, de forma ficcional, ricas em idéias condizentes com suas percepções, recordações e imaginações criativas. Revelar as sociedades, compostas de homens e mulheres (indivíduos, grupos ou subgrupos de indivíduos) com vidas cotidianas similares ou diferenciadas e fazer aflorar representações distintas do interior e da cidade de Belém eram partes de seus propósitos. $\mathrm{O}$ autor na busca de representações criou e recriou símbolos, sinais, imagens que, certamente, na ficção pareciam mais nítidas do que na realidade. $\mathrm{O}$ autor procurou, sem rigores acadêmicos, retratar por meio da ficção - sem recorrer a dados estatísticos ou registros históricos documentais - diferenciar a constituição já tradicional de uma sociedade rural e confrontá-la com a sociedade urbana, ou seja, descrever sociedades distantes, porém, similarmente desiguais, realizando obras que, em muitos sentidos, eram mistos de história, sociologia, geografia, antropologia e talento literário. Tratava-se de registros literários das condições geográficas e dos modos de vida social no interior em Cachoeira e na cidade de Belém a partir de personagens emblemáticos, extraídos ou criados como pertencentes às camadas pobres ou populares que buscavam no presente ou no passado ascensões sociais e econômicas, por casamento, por estudo ou por emprego público ou privado.

Com sua obra, o autor rememora ou recria vidas sociais e cotidianas, no Marajó e na cidade de Belém, umas marcadas pela inferioridade outras pelo poder e "mandonismo", porém, tais diferenças eram vistas quase sempre como naturais pelos personagens, isto é, como posições diversas que a Natureza lhes impôs. Enfim, o autor dos romances aqui analisados, certamente, emprestava suas memórias, e suas experiências vividas aos seus personagens. Os livros por nós selecionados compuseram, assim,

Revista da ANPEGE. v. 3, 2007 
um conjunto de obras marcadas pelas memórias seletivas da infância do autor e por isto mesmo, cheias de visões subjetivas, porém, às vezes, entremeadas do concreto, ou seja, de fatos objetivos contados e recontados e ainda percepções subjetivas.

As obras de Dalcídio Jurandir funcionam, de certa forma, como leituras possíveis das realidades físicas e sociais de uma porção do Marajó polarizada por Cachoeira e por Belém, habitada por indivíduos que desejaram ou ainda desejam ascender social e economicamente. É preciso esclarecer mais uma vez que o interior de que trata o artigo se restringia a maior ilha da foz do rio Amazonas paraense, na primeira metade do século XX. Basicamente, neste momento, o Pará, como o resto do país, era marcado por fortes contrastes entre as paisagens, as condições materiais e imateriais de vida, as condutas, os hábitos e os costumes na capital (cidade de Belém - que havia vivido a experiência da Belém da Belle-Époque - vide SARGES, M. N., 2000) e nas áreas interioranas, incluindo pequenas aglomerações, pequenos núcleos populacionais, embriões de futuras cidades e o espaço ainda rural e dominantemente pastoril, no caso dos campos de Marajó.

As intenções do autor pareciam consistir nas representações de uma época, ou seja, de um momento histórico marcado por forças históricas e pela transição lenta e gradual das mentalidades dominantes num período de passagem da Monarquia para a República, ou seja, tratava-se de um período correspondente ainda a da jovem República. Para Rosa Acevedo, ainda “a própria obra de Dalcídio Jurandir é contemporânea dos fatos dessa [época de] transição, de um quadro de relações e tensões sociais da sociedade que rompia com o regime escravista. O autor lança mão de memória e experiências desse tipo." No caso específico de Belém do Grão Pará, o autor tratou das conseqüências psicossociais das transformações de uma sociedade de província no contexto do Império para uma sociedade urbana do início do processo de crescimento das sociedades urbanizadas (ou em processo de urbanização) vinculadas à República. Dalcídio, portanto, descreveu indivíduos que (re)viviam o passado: ex-aristocratas, ex-cortesões, criados e marginalizados do mundo rural e da cidade; dos ricos, das classes médias ressentidas e dos pobres. Abordou um período de transição lenta, e que implicava, antes de tudo, em transformação mental e gradual.

A cidade de Belém e o interior, áreas relativamente distantes da capital, pareciam se constituir em partes de um mundo aparentemente muito distante e muito distinto. Estas diferenças incentivavam e ainda incentivam a busca de variados representantes das classes sociais ${ }^{6}$ e das etnias ${ }^{7}$ pela cidadecapital,

seduzidos pelos encantos, pelos "benefícios" da vida moderna, isto é, da convivência "civilizada" (da urbanidade) na cidade central, pela proximidade da pequena corte ou da sede do governo local.

Perceptivelmente, por detrás de suas narrativas do cotidiano dos indivíduos, Dalcídio representou as sociedades de Marajó, particularmente, de Cachoeira e de Belém, identificou e descreveu paisagens "naturais" modificadas pelas relações entre a Natureza e as sociedades (rurais e urbanas), enfatizou posições sociais e os sonhos dos indivídos ou grupos de indivíduos atuais e passados de ascensão social, e ainda realizou uma crítica social, embora dele não se possa cobrar rigor e significados históricos rígidos tal como se faz com os membros de uma academia vinculada às ciências sociais.

\section{De que Região Marajoara Falava e de Onde Escrevia Dalcídio Jurandir?}

$\mathrm{O}$ uso do termo região, em geral vinculado à geografia, encontra-se associado à idéia de nomeação, de unidade e de divisão. O processo de unificação implica na centralidade das cidades e na conectividade hierárquica ou em rede dos núcleos (lugares ou pontos de aglomerações populacionais) e nas relações deste com uma cidade maior (cidade-região, cidade central). O processo de nomeação está inserido num campo de forças que orienta quem nomeia e como nomeia, enfim, com critérios predefinidos, ou seja, a 
definição de uma região depende dos interesses e das estratégias de grupos sociais que atuam econômica e políticamente sobre ela. Por sua vez, a sua existência depende do jogo de classificação, do modo de conhecer, que não é outro senão princípios de entendimento sobre o objeto ou a realidade estudada. Estes são (re)orientados por estratégias políticas, ações ou práticas sociais e repertórios anteriores dos atores envolvidos na construção da noção de região. Todavia, esta discussão, certamente, foge ao escopo de nosso trabalho.

Para muitos autores, o Marajó não formava propriamente uma região, mas era e é uma extensa ilha fluvio-costeira de $48.000 \mathrm{~km}^{2}$, situada na desembocadura do rio Amazonas, no litoral paraense. Ao oeste e ao norte, a ilha é limitada pelo Rio Amazonas; ao nordeste pelo oceano Atlântico; ao sul pela Baía do Marajó, pelo prolongamento da foz do rio Tocantins e pelo rio Pará, braço fluvial que se comunica, por meio dos furos de Breves, a sudoeste, com a foz do rio Amazonas (FERREIRA, 2003, p. 341; IBGE, 2000).

Em face dos obstáculos às comunicações entre suas diferentes áreas geográficas, havia e ainda há dificuldades de se identificar unidade no Marajó. Vista à distância, a vegetação (campo e mata) divide a ilha do Marajó em duas porções distintas geográfica e economicamente, ou melhor, o conjunto de seus aspectos físico-geográficos da ilha e a diversidade de suas economias (essencialmente pecuária, de um lado, e extrativismo, madeireiro e não madeiro, do outro) ajudavam e ainda ajudam a separar a ilha em Marajó ocidental e oriental. No Marajó oriental, a natureza campestre e o ribeirinho colaboraram para a não grande diferenciação das várzeas, das margens ou beiradas de rios (costa sul e costa norte, costa leste e costa oeste) da ilha que se alagam ou estavam sujeitas ao alagamento no verão, e da terras-firmes no centro-oeste do Marajó, repletas de lagos que transbordavam no inverno e que secam no verão. As grandes fazendas de gado foram e ainda são as instituições mais douradoras do Marajó centro-oriental.

O Marajó retratado por Dalcídio Jurandir limitava-se à porção oriental ou leste (formada de vegetação campestre, ocupada pela pecuária extensiva). Este Marajó foi tornado, sem dúvida, no palco da tensão entre o interior marajoara e a cidade de Belém (sede municipal do estado do Pará). Jurandir, ao optar por esta área geográfica específica do Marajó, radiografou ali os ritmos de vida, os ciclos das águas (enchentes/campos encharcados ou secas/campos queimados), observou e registrou trajetórias de vidas experimentadas pelas suas personagens nesta porção do Marajó. A idéia, portanto, foi apresentar a imagem daquela dialética, na qual as mentalidades dos indivíduos do interior-rural e do urbano, representado especificamente pela capital, se entrecruzam, expondo uma visão particular do mundo amazônico paraense nas primeiras décadas do século XX.

\section{Quais os Lugares Marajoras Representados nos Romances de Dalcídio Jurandir?}

Dalcídio Jurandir circunscreveu o espaço de circulação de seus personagens a Cachoeira e a Muaná (de onde veio o Major deixando para trás três filhas de seu casamento anterior). Há menções a Afuá e Anajás. Porém as duas primeiras - Cachoeira e Muaná - eram os lugares de vida coletiva cujos dramas humanos descritos se entrelaçavam e eram melhor observados ou vividos pelas personagens (Figura 1). Cachoeira, cidade maior e Muaná, ambas espaços antigos que tiveram origem em antigas fazendas, vivem até os dias atuais do gado, da lavoura, do extrativismo vegetal (particularmente do açaí) e da produção artesanal da farinha e do pescado. Belém era ainda para as classes pobres uma miragem, ao mesmo tempo, um caminho de fuga determinado pela ilusão de uma vida promissora, não obstante suas mazelas já decantadas. Só os mais abastados sonhavam com Lisboa ou Paris ou Londres. 


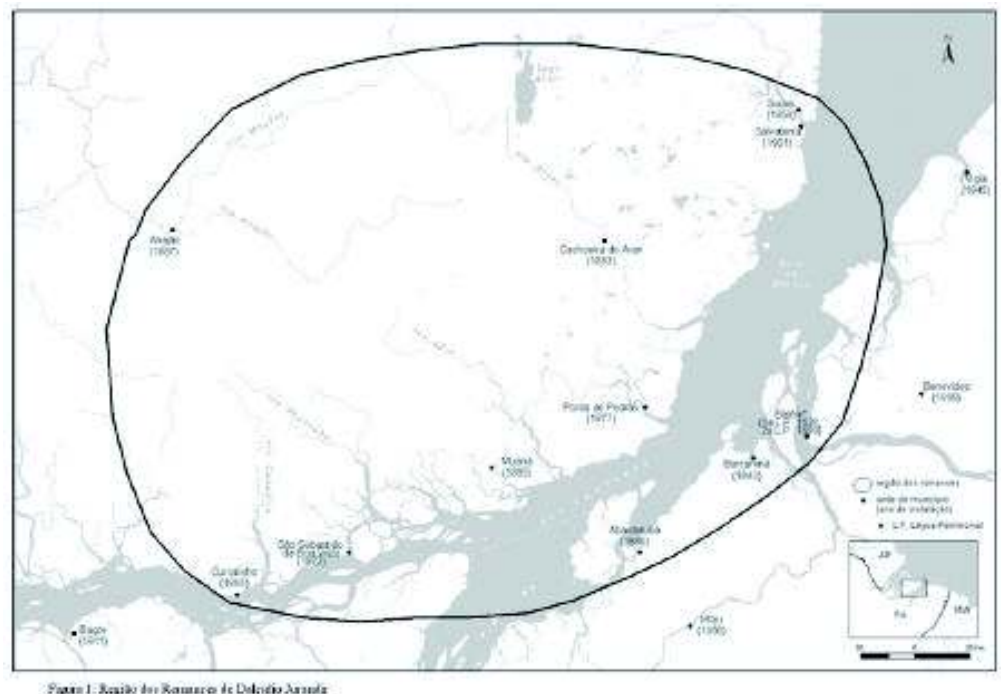

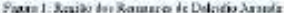

Dálcídio descreveu os modos de vida dos grupos (e subgrupos) de indivíduos que viviam entre rios (as populações ribeirinhas) e campos (secos, alagados ou alagáveis). Nas obras deste autor, as vidas ligadas às águas, aos rios, aos lagos, aos ciclos (sazonalidade) das águas e das secas (campos alagados pelas enchentes no inverno e os campos secos e queimados no verão) eram ressaltados.

$\mathrm{Na}$ terra preta do fogo o autor fez referências aos gaviões: “[...] os gaviões caçavam no ar os passarinhos tontos" (JURANDIR, 1998, Chove nos Campos de Cachoeira, p. 117). Numa leitura alegórica, passível de ser interpretada a partir da estrutura fundiária local desigual, que aquela terra "preta do fogo" não era outra se não dos potentados locais ("gaviões"), que alijavam das terras comuns os camponeses ("passarinhos"). No final do romance os campos são cercados para formar a fazenda "Bem Comum" do Dr. Lustosa, o qual justificava o cercamento para protegê-los, pois, para ele [Dr. Lustosa]: "[...] o grande mal do Brasil está na derrubada sistemática das nossas matas" (JURANDIR, 1998, Chove nos Campos de Cachoeira, p. 393). Os desejos dos personagens de deixarem os campos alagados manifestaram-se na seguinte passagem:

Uma nuvem mais pesada de chuva cresceu no céu. Quando chove, Cachoeira fica encharcada. Os campos de Cachoeira vinham de longe olhar as casas da vila à beira do rio, com desejo de partir com aquelas águas." (JURANDIR, 1998, Chove nos Campos de Cachoeira, p. 23).

Os indivíduos pobres (sem terra e sem trabalho) migravam para a cidade e "continuam com os pés no chão cachoeirense" (JURANDIR, 2004, Belém do Grão Pará, p. 96), mais particularmente, às margens dos rios e igarapés. Os ribeirinhos tendiam a permanecerem ribeirinhos só que agora às margens das estradas. Assim, escreveu Dalcídio:

Um trem apitou e passou, vagorosamente, arrastando-se, fazendo a casa, de leve, estremecer. Alfredo arriscou um olhar pela janela, um trem pela primeira vez. Quase o mesmo apito que ouvia das lanchas no chalé. Em vez de barcos, da "Lobato" e da "Guilherme" passavam trens. Vinha, com efeito, morar à margem de outro rio? (JURANDIR, 2004, Belém do Grão Pará, p. 96-97). 
Isto podia refletir o fato de que para o protagonista, Alfredo, os indivíduos, migrantes de Cachoeira, permaneciam à margem, agora habitantes das margens das estradas por onde se estendem as periferias urbanas. Podemos interpretar também que a ruralidade permanecia nos olhos de quem observava.

\section{PERSONAGENS E REPRESENTAÇÕES}

O escritor se impõe a liberdade de criar ou de retratar seus personagens das narrativas sem censurá-los, sem moralismo e com maior ou menor distanciamento ou discrição. O romancista seleciona e escolhe quem representar e, a partir das anotações acerca de imagens recorrentes apresentadas, deixa ou faz com que seus personagens se apropriem das imagens observadas (lembranças registradas em algum momento de sua vida), manifestando, assim, o seu desejo de vê-las reproduzidas e difundidas. No entanto, para Barthes “a explicação do Desejo é ilusória" (BARTHES,versão 2005, p.70)

\section{Construções das Personagens de Dalcídio Jurandir: Estados Mentais e Representações Imagéticas do Interior-Rural e da Cidade-Capital}

Como já foi dito anteriormente, Alfredo sentia as contradições de ser um mestiço ("branco sem ser branco"). Sua mãe negra, Dona Amélia não era formalmente casada com o Major. Por conseguinte, não era legitimada pela "alta" sociedade cachoeirense, temia ser confudida com as "moças da rua das Palhas". Por outro lado, ele não era um moleque de beira de rio "sem eira nem beira", já que não era um dos moleques sujos de pé no chão. Esta situação limite o incomodava, pois não se incluía inteiramente em nenhum "mundo". Talvez, isto explicasse sua fixação em ir a Belém para estudar. Isto é, buscar um reconhecimento para se destacar e permitir "ser alguém" (mudar ou definir sua posição ou status social). Ele queria fugir do paludismo (malária) e das marcas de feridas que o atormentavam, que eram consideradas indícios de uma baixa distinção social. De fato, ele não era possuidor de pernas limpas como os felizes meninos Tales e Jamilo, os quais deveriam pertencer à elite local.

A passagem abaixo extraída do primeiro capítulo de Chove nos Campos de Cachoeira, que nos permite realizar um trabalho de interpretação na qual articulamos análise micrológica das narrativas com o seu significado no contexto social, que o texto lhe era devedor.

Voltou muito cansado. Os campos o levaram para longe. O caroço de tucumã o levara também, aquele caroço que soubera escolher entre muitos no tanque embaixo do chalé. Quando voltou já era bem tarde. A tarde sem chuva em Cachoeira lhe dá um desejo de se embrulhar na rede e ficar sossegado com quem está feliz por esperar a morte. Os campos não voltaram com ele, nem as nuvens nem os passarinhos e os desejos de Alfredo caíram pelo campo como borboletas mortas. Mais para longe já eram os campos queimados, a terra preta do fogo e os gaviões caçavam no ar os passarinhos tontos. E a tarde parecia inocente, diluída num sossego humilde e descia sobre os campos queimados como se os consolasse. Voltava donde começavam os campos escuros. Indagava por que os campos de Cachoeira não eram campos cheios de flores, como aqueles campos de uma fotografia de revista que o seu pai guardava. Ouvira Major Alberto dizer à D. Amélia: campos da Holanda. Chamava-se a isso prados (JURANDIR, 1998, Chove nos Campos de Cachoeira, p. 117).

As ambigüidades dos sentimentos do personagem Alfredo eram notáveis quando contemplava ou se deleitava com a "natureza", ou ainda quando se confrontava paisagens e indivíduos rurais com quadros e moradores urbanos. Havia "inocência e ambição". "Também havia no rapaz a sede da cidade desconhecida" (JURANDIR, 1994, Três casas e um Rio, p. 391). E buscava na imaginação a visão de Belém, "as luzes de Belém", a Belém dos colégios. "Compreender a cidade, aceitá-la, era a sua necessidade" 
(JURANDIR, 2004, Belém do Grão Pará, p. 85). Havia, portanto, em Alfredo "uma crescente gula da cidade" (JURANDIR, 2004, Belém do Grão Pará, p. 93).

A existência do objeto mágico era representado pelo caroço de tucumã. Este claramente com poder encantado. Assim, tem sido lugar comum numa certa tradição interpretativa da obra dalcidiana identificar o caroço de tucumã como um artifício mágico ou mítico, que transmuta, para Alfredo, oduro cotidiano cachoeirense em "imagens de desejo", por meio de seu poder de faz-de-conta, a saber, "com um carocinho daqueles imagina tudo, desde o Círio de Nazaré até o Colégio Anglo-Brasileiro" (JURANDIR, 1998, Chove nos Campos de Cachoeira, p. 191). O carocinho de tucumã estava para instrumento mágico de Alfredo assim como os catálogos provindos da Europa, estavam para o seu pai, Sr. Alberto, e as estórias de Salu (pequeno comerciante português, dono de uma taberna decadente) para Lucíola e para outros habitantes pobres de Cachoeira. As estórias de Salu os faziam esquecer do Marajó e os transportavam para outras realidades ou situações mais interessantes. Contudo, há de se adotar uma perspectiva desmistificadora e reveladora pela interpretação, o expediente mítico utilizado pelo narrador como apenas um medium-dereflexão, de mostrar as imagens que povoam as mentes, os sonhos, os corações e os desejos de cada um.

Sem precisar de auxílio de instrumentos mágicos, as imagens de Marajó, particularmente dos campos de Marajó, foram vistas e descritas de forma a ressaltar suas belezas, e as variações naturais nos ciclos das águas. Elas foram utilizadas para demonstrar o encantamento das relações do indivíduo, ainda criança, com a "natureza" regional/local, ilustrando a identificação do protagonista com a terra. Também a alusão a "campos queimados" podia sinalizar tanto a passagem de tempo (os ciclos da água) quanto a presença da herança cultural: a prática agrícola comum do corte-e-queima na Amazônia. O narrador se utilizou de subterfúgio metafórico para amenizar a interferência humana, ao comentar que os campos queimados eram consolados pela Natureza, representada pela "tarde inocente". Foi pela fala do Major que veio a dura constatação: "Uma gente que não se corrige. Não se convencem que não devem queimar os campos [...]. Por que [...]. Esteriliza [...]" (JURANDIR, 1998, Chove nos Campos de Cachoeira, p. 120). Contudo, quem é esta "gente" citada pelo Major? Vaqueiros, camponeses/pequenos produtores familiares, ribeirinhos (que viviam entre os rios e os campos) ou não, despojados ou não de suas terras, pecuaristas/ fazendeiros marajoaras? Os produtores familiares de subsistência/os camponeses do Marajó tinham suas terras incorporadas a grande fazenda, como foi o caso já mencionado da fazenda "Bem Comum".

Alimentado obscessivamente pelo sonho de estudar em Belém, Alfredo construiu uma imagem de desejo desta cidade-capital a partir da narrativa de Siá Rosália, que viajava mensalmente para a cidade na busca do seu montepio (pensão). E ao chegar, vinha contar para Alfredo a beleza da cidade que ele não viu quando, ainda bem pequeno, esteve lá. Esteve em Belém acompanhando os pais, quando foi "abandonado" no barraco da tia de sua mãe, Ciana, enquanto eles passeavam pela cidade.

A cidade de Ciana era uma "cidade triste, cheia de lama, com meninos sujos, homens rotos e tisnados que passavam carregados de embrulhos, com carrinhos de mão vendendo bucho" (JURANDIR, 1998, Chove nos Campos de Cachoeira, p.190). Esta cidade era muito diferente da cidade de Siá Rosália, feita "de bondes elétricos, arraial de Nazaré, largo da Pólvora, as lojas de brinquedos" (JURANDIR, 1998, Chove nos Campos de Cachoeira, p.204). Dona Rosália "lhe trazia as senhas da cidade" (JURANDIR, 1998, Chove nos Campos de Cachoeira, p.204). Estas eram bilhetes dos bondes que ela trafegava pela cidade. Ao olhar aquelas senhas se embriaga imaginando em bondes mágicos correndo pela cidade. Belém era sua salvação, queria fugir de sua condição: "Seu terror era ter de ficar naqueles campos [...]. Acabava vaqueiro, andando de perna aberta de tanto viver enganchado em costa de boi velho" (JURANDIR, 1998, Chove nos Campos de Cachoeira, p.314). 
Após muita lida de sua mãe, ele partiu para Belém. Enfim, poderia "encontrar e conquistar Belém, ver o mundo que os matos e as nuvens escondiam teimosamente" (JURANDIR, 1994, Três casas e um Rio, p.391). A viagem à cidade, no barco São Pedro, não é só a travessia da baía, mas também um momento de passagem. Um rito de separação, entre condição de menino matuto em Cachoeira e o futuro citadino. Este momento se realiza no seu primeiro ato, ao chegar ao Ver-o-Peso: de cortar o cabelo. Neste pequeno cerimonial, numa barbearia da cidade, o ato de rapar a cabeça foi emblemático concretizando o rito de separação, pois com as mechas que caíam lá se ia [embora] Cachoeira. Estava pronto para Belém. Ao tomar o bonde para se dirigir à casa de ${ }^{\circ} 160$, na Gentil - local de moradia dos Alcântara, onde ia ficar - foi tomado de uma embriaguez, pareceu que estava ainda no barco e as ruas eram "um rio ondulante." (JURANDIR, 2004, Belém do Grão Pará, p. 95.)

A partir do romance Belém do Grão Pará, afirmamos que esta relação entre interior e cidade não era "aparentemente" só de oposição, mas também de circularidade, ou melhor, que remetia a si mesmo e se fechava sobre seus limites. Em outras palavras, essa relação parecia não ser de uma inferioridade/superioridade ou de subordinação/dominação. Com isso, não se quer afirmar que não exista tensão entre o espaço social do interior (englobando vários locais da região do Marajó) e o da capital, Belém. É importante que se afirme diferentemente de Maria Isaura Pereira de Queiroz (1979), que os valores do rural e da cidade nos romances citados não se encontravam numa "implicação mútua" e nem numa "complementaridade". Aquela "tensão dos extremos" será mais bem demonstrada na leitura do seu entretecimento na forma literária. Entretanto, podemos adiantar que a estruturação dos romances se constrói segundo o "ritmo geral da sociedade", no caso o da Amazônia, ou melhor, do Marajó e de Belém. Este ritmo sofria influência da confrontação do tempo cíclico (da Natureza) com o tempo linear (tempo do capital) ou com o tempo lento e complexo das mentes dos indivíduos organizados em sociedade.

Neste romance, além dos personagens emblemáticos o autor dizia também dos lugares simbólicos como o Ver-o-Peso, a cidade velha, as praças e os centros comerciais, das áreas de expansão da cidade), dos parques, das praças públicas e dos bosques, dos cinema do teatro (Teatro da Paz), ou seja, dos espaços que compunham e alguns deles ainda compõem a cidade de Belém. Enfatizava, particularmente, o Ver-o-Peso, espaço de entrada e saída de Belém para os que vinham das ilhas.

Assim, o Ver-o-Peso era e é ainda o espaço de primeiro contato dos habitantes das ilhas pertencentes à Belém ou das ilhas do Arquipélago do Marajó com a cidade de Belém. Era e ainda é um espaço de trocas de mercadorias, de informações, de encontros e de negócios. E ainda é o espaço de comércio, trânsito e de transição que guardava - nos cheiros para uns e no ar fétido para outros ("A senhora sem despedir-se, fechou o leque, que mantinha à distância os barcos, a intimidade, os fedores do Ver-o-Peso" (JURANDIR, 2004, Belém do Grão Pará, p. 84).

Espaço portuário e de mercado, o Ver-o-Peso representava para os habitantes das ilhas, especialmente, um conjunto paisagístico de celebração de uma ruralidade ainda não perdida, ou não esquecida. Trata-se de uma zona fronteiriça entre o interior-rural e o urbano. Na chegada a Belém, o narrador descreveu que Alfredo perdia "o chão de Cachoeira e não sentia ainda o chão de Belém" (JURANDIR, 2004, Belém do Grão Pará, p. 113).

Em alguns trechos de Belém do Grão Pará, Dalcídio Jurandir de diferentes maneiras, descreveu o Ver-o-Peso:

Viva maré de março visitando o Mercado de Ferro, lojas e botequins, refletindo junto ao balcão os violões desencordoados nas prateleiras. Os bondes, ao fazer a curva no trecho inundado, navegavam. As canoas no porto veleiro, em cima da enchente, ao nível da rua, de velas içadas, pareciam prontas a velejar cidade adentro, amarrando os seus cabos nas torres do Carmo e da Sé, de Santo Alexandre e nas samaumeiras do arraial de Nazaré. Libânia corria então para ver: os bons barcos, panos cor de telhas, cobrindo o Ver-o-Peso com telhado de velas (JURANDIR, 2004, Belém do Grão Pará, p. 133). 
Ao chegarem ao Ver-o-Peso, lhe apeteceu uma tainha fresca e Alfredo via então uma nova cidade, agora sem Libânia, meio bruta, que lhe pedia dinheiro em troca de peixes, carnes, frutas e verduras, panelas de mingau, prateleiras de cheiro, dentes de boto, línguas de pirarucu, cascas e raízes, defumações e ninhos de gavião-coré contra mau olhado, quebranto, contra qualquer gênero de infelicidade. Seu Alcântara, comseu conhecimento meticuloso de mercados, conversava com este e aquele peixeiro, examina aqui a barriga da tainha, ali a gurijuba, peixe grande de comer homem. Adiante o monte de pratiqueira que lembrava a Alfredo os peixinhos nadando embaixo do chalé e em Belém, na panela de barro, nadando no tucupi (JURANDIR, 2004, Belém do Grão Pará, p.160)

Mesmo com o passar dos anos, os mercados de Belém, particularmente, aqueles da carne, do peixe, do açaí, das comidas e bebidas regionais, dentro ou nas vizinhanças do Vero- Peso, continuaram sendo os motores da economia do Marajó e das ilhas próximas a Belém, etc.

O Ver-o-Peso significava também o espaço, onde o recém-chegado despia de sua matutice para enfrentar o mundo da cidade. Ali, no Ver-o-Peso, na chegada a Belém, Alfredo exibiu toda a sua insegurança. "Estaria andando direito como menino da cidade? [...] Também na cidade saberiam descobrir os que vinham do sítio, tios-bimbas no caminhar e no admirar tudo?” (JURANDIR, 2004, Belém do Grão Pará, p. 81).

$\mathrm{O}$ autor registrou todas as inseguranças de Alfredo, de um lado, todas as confusões sentimentais de quem deixou para trás, a família, o modo de vida "incivilizado", de um lado, e seu deslumbramento e descobertas da cidade e do estilo urbano, civilidade, em sua chegada em Belém. O receio de sua matutice e do estigma dos "tios-bimbas" o perseguem.

Deslumbramento e insegurança aparecem em diferentes trechos:

Alfredo, então avançou pela proa e saltou na calçada, pisando o chão da cidade. Viu que andava sobre parale-
lepípedos. Numa dessas pedras levada pelo Alfer, 'moço' da lancha 'Atatá', se apoiava a trempe do fogão da
nhá Porcina. Por entre as pedras no chão da cidade grelava capim. Que luz a do seu olhar cheio de uma cidade
que era só sua, não daqueles barqueiros nem de sua mãe nem daquela gente alheia e indiferente que passava.
Sua. Mas no ruído, nas vozes do Ver-o-Peso e no íntimo rumor de suas emoções, caía como água de fonte a
voz de Andreza: 'Belém'. Sentiu-se ferido por uma piedade miúda e uma tristeza que agradava ao mesmo
tempo seu orgulho de estar na cidade. Pobrezinha de Andreza, que não estava a seu lado e que, por certo,
vendo o automóvel, não daria aquele grito de matutice (JURANDIR, 2004, Belém do Grão Pará, p. 80-81).

A cidade ria dele (JURANDIR, 2004, Belém do Grão Pará, p. 92).

Os sentimentos contraditórios ora de culpa perante a mãe: "nunca lhe pago tudo isso, mamãe, nunca mesmo ...", disse Alfredo (JURANDIR, 2004, Belém do Grão Pará, p. 107) - ora de se libertar de Cachoeira, fazem parte de uma luta interna travada entre as necessidades de Alfredo e a saudade da mãe, de Andreza e de Cachoeira:

[...] aquela preocupação pela mãe. Que estaria fazendo ela no chalé?” (JURANDIR, 2004, p. 112).

A luta entre Cachoeira e Belém lhe aumentava a solidão. Cachoeira era, sobretudo, a mãe sozinha, cambaleando, a inovocar a filha, chamando as bruxas espetadas nas estacas do quintal. Pai e mãe, a irmã morta, absolutamente separados, desapareciam da ilha perdida (JURANDIR, 2004, Belém do Grão Pará, p.114).

Ao mesmo tempo queria afastar de si toda Cachoeira. Desde o Caroço de tucumã até Andreza (JURANDIR, 2004, Belém do Grão Pará, p.114).

Belém, em muitos sentidos, continuava a ser vista como uma ex-sede de uma pequena"Sociedade de Corte", Alfredo por meio das Alcântaras entrou em contato com objetos simbólicos ou monumentos 
históricos, bem como, com ex-membros de uma "Sociedade de Corte" provinciana e decadente. Belém, distante do Rio de Janeiro, que abrigava a grande corte, ou seja, a Corte do Império, passou também a comportar-se, com a produção de riquezas da borracha, com uma sociedade de corte. O intendente (prefeito) Antônio Lemos tornou-se implementador de um projeto grandioso de fazer de Belém (isto ocorreu também em Manaus), réplica de Paris, projeto este que estava em processo de implantação no Rio de Janeiro. Transformações urbanísticas ocorriam, já nos anos 1890, nas capitais dos distantes estados do Pará e do Amazonas (DAOU, 2000).

Belém, tal como no Rio de Janeiro, contou com mudanças no traçado da cidade, como o alargamento de ruas, as construções de bulevares, de monumentos diversos, etc. que produziram conseqüências nas formas de sociabilidade da elite e efeitos sobre as classes que serviam às elites e trabalhadoras burocráticas. As expressões das mudanças eram diversas, no período que se convencionou denominar de "Belle Époque" (SARGES, 2000). Evocamos de novo portanto, a análise sociológica de Elias para entender a sociedade de pequena corte que teve lugar na Belém, da economia da borracha. Sua decadência era lamentada pelos antigos aristocratas ou cortesões:

O importante era ter mantido o Senador, continuasse a reluzir e a gozar, dando-se ao luxo, famoso em todo o Norte, até mesmo em Portugal, de instalar em Belém, à sombra da Catedral e da estátua do general Gurjão, a pequena corte que tinha por símbolo a gardênia e era pelos letrados comparada às cortes do tempo de Lourenço, o Magnífico (JURANDIR, 2004, Belém do Grão Pará, p. 63).

Durante os períodos áureos da economia da borracha, as agendas do teatro da Paz eram repletas de atividades. Havia também os bailes, as festas cívicas, as celebrações no Bosque. O lemismo era marcado pelas lembranças da pequena corte. Falando sobre Emilinha, como uma expertencente da corte, o autor escreveu:

De suas lembranças do lemismo preferia a das paradas escolares, as aulas de piano, aquela viagem para o Bosque no bonde de luxo entre flores, fitas e muitas bandeiras do Pará e do Brasil; as duas pirâmides de lâmpadas policrômicas com as armas do município, as piras de gás, o redondel do Parque Batista Campos, onde viu os touros; a grande boneca alemã e o trem que corria na 22 pelo corredor (JURANDIR, 2004, Belém do Grão Pará, p. 72).

Sim, Emília desejou que as janelas da vizinhança ficassem repletas para ver o piano chegando; dava a medida das posses e da educação das Alcântaras." ... "Nunca o piano a servira tanto como naquela tarde" (JURANDIR, 2004, Belém do Grão Pará, p. 310).

Nas casas dos antigos cortesãos havia piano que era mantido como um símbolo do gosto da corte, também demonstrado nos trajes à moda francesa e nas relações entre senhores, damas e servos. Porém, a época descrita era de aparências repletas de imagens e símbolos da corte ou do progresso,vistos já como sinais de decadentes. Os sentimentos de muitos personagens refletiam o fim de um sonho ou de uma era.

\section{As Posições Sociais e as Buscas Individualizadas de Ascensões Sociais e Econômicas}

Fugir aos abusos dos patrões, ascender individualmente na vida via casamento ou emprego sempre foram metas dos pobres, dos oprimidos que buscavam e ainda buscam mudar de posições sociais, fugindo de um destino marcado. Tais metas alimentavam similarmente habitantes do interior e da cidade de Cachoeira no Marajó, bem como, de Belém.

Os abusos dos antigos, agora arruinados senhores de terra, ou dos atuais (época descrita nos romances), grandes proprietários, foram apresentados dentro de um contexto de regime de propriedade sem 
muitas transformações em seu conteúdo, mostrando que embora decadentes as formas dominantes de "patriarcalismo" e "mandonismo" não desapareceram de vez do Marajó. Isto não chegou a ser uma grande novidade ou revelação nova para o leitor conhecedor do Marajó, que associará o regime de propriedade e as relações entre patrões e subordinados às estórias descritas pelo autor como pertencentes aos longos ciclos de uma história quase contínua, quase não marcada por rupturas no desenvolvimento do binômio grande propriedade-pequena unidade familiar de subsistência.

Os casamentos fora de sua categoria social eram inconcebíveis, ainda que ambicionados pelos que pertenciam as categoris inferiorizadas. Assim, relações entre donos, ou mesmo, ex-donos de terra, e moças de origem humilde, eram, portanto, complicadas e impossíveis de serem assimiladas e imaginadas socialmente. Havia um sadomasoquismo no personagem Lucíola, uma solteirona, frustrada por não ser ela a mãe de Alfredo - que se resignava às hostilidades do menino e aparecia aceitar como algo absurdo, porém, inelutável, o casamento, embora não compreendia se era perversão ou as maldades de Edmundo Meneses, neto e herdeiro de uma grande fazenda em ruínas, que se preparou para ser um grande proprietário, e que, após se educar na Inglaterra, voltou pobre para o Marajó, onde circulava como um proprietário-fantasma das ruínas da antigamente próspera Fazenda Marinatombalo.

Para Lucíola o casamento por conveniência, sem amor, já não fazia mais sentido. Para Edmundo, talvez, o "casamento era uma das suas maneiras de anular-se inteiramente, aceitar a ruína e ficar solitário com os crimes de Edgar Meneses" (JURANDIR, 1994, Três casas e um Rio, p.366). Edmundo, de um lado, o seu falecido avô, sua avó, seu falecido pai e seu tio Edgar Meneses, de outro, eram protagonistas e, ao mesmo tempo, testemunhos de relações de patronagem, de relações de enriquecimento às custas do trabalho subserviente (não pago ou irrisoriamente remunerado) e do processo de expropriação das terras aos produtores familiares pauperizados, empurrados para as margens dos rios e para as periferias pobres da cidade. Estas eram histórias de exploração e de crimes impunes, ainda presentes no imagiário coletivo ou na memória dos marajoaras. O autor, conscientemente, confrontou a dura realidade do Marajó com a dos idealizadores do progesso dos que sonhavam com a cidade.

No livro Belém do Grão Pará, o autor mudou os personagens e seus pontos ou locais de observação, subvertendo, modificando os olhares sempre reflexivos de alguns de seus personagens.

Para o menino Alfredo, descortinar o Marajó, sem futuro, e destruir os mitos de uma Belém de imagens para ele abstratas, porém, fantasiosas, não era problema. Entre ideais ambicionados de vida e a ausência de experiências concretas (ainda não vividas enquanto habitante da cidade real) que lhe provessem um quadro mais claro das dinâmicas e figurações sociais associadas à cidade de Belém, ele não ignorava os dramas locais ou citadinos, e nem os sonhos desfeitos de muitos indivíduos em relação à Belém, como foi o caso de Eutanásio, seu irmão, que retornou de Belém para o Marajó, marcado por frustrações. Para o menino Alfredo, a cidade representava, no entanto, a oportunidade de se educar, de definir sua posição social e isto era o que importava ao garoto. Nada, entretanto, o impedia, nos anos 20 do século XX de se decepcionar com Belém - a Paris decadente do Senador Antônio Lemos, o ex-Intendente (ex-prefeito) Municipal de Belém, - e com uma sociedade, enriquecida anteriormente com a borracha, agora (década de 1920) em ruínas e de retratá-las com olhares críticos e irônicos.

“'Belém, B'lém, Belém, Belém', repetia Alfredo baixinho, imitando Andreza em Cachoeira quando fala da cidade" (JURANDIR, 2004, Belém do Grão Pará, p. 79). De um lado, o sentimento de saudade, de culpa de abandono da mãe e da amiga Andreza; e, de outro, a frustração com Belém, marcada por idéias de erros e de degradação por perda de posição social que aflige os antigos beneficiados da economia da borracha (os ex-aristocratas) e demais participantes da corte de Antônio Lemos - os reféns do lemismo (para quem, muitas vezes, as sementes da borracha levadas para o Ceilão e a queda do Senador Lemos 
eram as causas de toda uma situação de decadência econômica e de rebaixamento em suas posições sociais) que se agarram ao passado de aristocratas ou cortesãos e também dos pequeno-burgueses, e que vêem a nova realidade de modo acusatório e inconformado.

O autor planejou, assim, comunicar o que o leitor já conhecia da história da Amazônia e de Belém, mas destacando o que seus diferentes personagens observavam e como pensavam particularmente, seu Virgílio, Dona Inácia e Emília, filha de ambos, sobre a situação política, econômica e social da cidade de Belém. Vejamos alguns trechos:

Na rotina da capatazia, diante do cais murcho, as 'gaiolas' em seco e os armazéns fechados, seu Virgílio foi se convencendo de que tudo aquilo não viera apenas da queda da borracha. Mas de que mal? ... A cidade exibia os sinais daquele desabamento de preços e fortunas. Fossem ver a Quinze de Novembro com seus sobrados vazios, as ruínas d'Província, os jardins defuntos, a ausência de cal e de brilho nos edifícios públicos e nos atos cívicos. (JURANDIR, 2004, Belém do Grão Pará, p. 63).

Para as mulheres, a queda do Senador era a causa de tudo. A borracha subira a tanto, graças ao Senador, em Palácio (JURANDIR, 2004, Belém do Grão Pará, p. 63).

Os modos de pensar e agir dos indivíduos mudaram com a crise pós-borracha. Ficaram as lembranças e o inconformismo (com as mudanças não favoráveis de posições sociais) que nutriam os lemistas. As patologias sociais e os dilemas existenciais intrigavam Alfredo e povoavam seus pensamentos sobre o Marajó e sobre Belém. Na cidade-capital, Alfredo descobriu que as paisagens e os personagens urbanos com os quais sonhara em Cachoeiras, eram símbolos ou testemunhas de uma dinâmica que tinha ficado para trás. Alfredo observava realidades sociais belenenses à distância, se colocando na linha fronteiriça para melhor virar tudo e todos pelo avesso e, assim, contrastar visões, modos de enxergar, de pensar e de agir.

A ambigüidade era a marca registrada dos personagens das obras analisadas de Dalcídio. No livro, Belém do Grão Pará, o autor tratou dos indivíduos outrora socialmente bem posicionados, mas que apesar de decadentes, preservaram os ares aristocráticos, como a madrinha-mãe, Dona Inácia Alcântara, e a madrinha Emília Alcântara. Isaura, ao contrário de Emília, "era a parenta pobre e parda, mais pobre e mais parda em contraste com a esmerada aparência das Alcântaras” (JURANDIR, 2004, Belém do Grão Pará, p. 204). A pobreza era realidade recusada por Emília, por isto ela e Isaura, sua amiga e prima, entraram em conflitos. Isaura não aprovava o casamento por interesse planejado como última cartada de Emília para garantir a si mesma um destino mais promissor, em face das incertezas quanto ao seu futuro, embora aquele estivesse longe de ser o casamento por ela desejado. Os irmãos de Isaura representavam as categorias de trabalhadores inferiorizados da cidade. Assim, Dalcídio confrontou os indivíduos inconformados com as mudanças sociais e políticas (D. Inácia, uma personagem irônica, cruelmente sarcástica e crítica do laurismo e saudosa do lemismo, por exemplo) com os aparentemente conformados. $\mathrm{O}$ autor vez por outra deixava escapar detalhes reveladores de como os indivíduos reagiam às transformações políticas e sociais:

[...] nas comidas, D. Inácia mostrava o seu avesso, o manso, o acolhedor, a maciez de dentro dela, que ela ocultava, mas temperado com os seus caprichos, gosto de ganhar no bicho, saudades do lemismo, raiva do laurismo [grupo favorável ao Governador Lauro Sodré], a orgulhosa satisfação de servir, exibir a sua competência" (JURANDIR, 2004, Belém do Grão Pará, p. 162).

Seu Virgílio Alcântara, migrante nordestino, marido de D. Inácia, uma figura ambígua, convivia com as dúvidas do passado: foi a borracha uma causa da decadência ou esta viria de qualquer maneira, foi ou não traído pela esposa no passado? Conformar-se com empreguinho público ou sujar as mãos com o contrabando; ter, ou não algo com a afilhada/criada Libânia?.

Revista da ANPEGE. v. 3, 2007 
Os personagens socialmente rebaixados, tais como os marginalizados, encontravam-se naufragados em rotinas ociosas e inoperantes, porém, prisioneiros dos ideais de um passado que se foi. Dalcídio confrontou comportamentos de lemistas e lauristas (grupos em torno do Governador Lauro Sodré que fazia oposições ao grupo defensor do Senador Antônio Lemos); descreveu novas e velhas gerações; confrontou ricos ou ex-ricos, bem-empregados com migrantes pobres, desempregados e famintos (os bandoleiros); patrões, padrinhos com os apadrinhados, criados (servos) tradicionais (Libânia e Antônio), os ex-criados, os "tios-bimbas" (indivíduos que reuniam as condições mista de negros, malandros, vilões e bobos) os oprimidos que encaravam como algo perfeitamente natural. A Libânia aceitava sua condição de recrutada para o trabalho doméstico não-remunerado, como se isto fosse natural. Libânia, o menino Antônio e, de certa maneira, o menino Alfredo representavam as crianças pobres exploradas (sem remuneração) que viviam nas casas de terceiros. Podemos ainda reafirmar que Dalcídio comparou comportamentos civilizados de uns e o retraimento e matutice de outros; descreveu áreas nobres da cidade (Estradas de Nazaré e São Jerônimo) e áreas de pobreza (Covões, atual Conselheiro Furtado); áreas do comércio e áreas residenciais e, ainda, habitantes do velho tempo que ocupavam o centro da cidade e os recém-chegados do interior, que se acumulavam nas periferias urbanas pobres.

\section{Distâncias Vividas: Distâncias Físicas, Sociais e de Mentalidades}

Os distanciamentos sociais e de mentalidades podem ser tão ou mais importante sque o físico, considerando as diferenciações sociais, distâncias e os espaços vividos no âmbito dos quais se estabeleceram práticas, modos de vida, percepções, visões de mundo, os indivíduos constroem representações (atribuem significados) distintas às paisagens, a objetos específicos, aos hábitos e gestos ou às formas de comportamentos, em geral.

Ao analisar a diversidade ecológica e cultural do delta interior do Níger (área caracterizada como pré-industrial), tomando por base o espaço-padrão das sociedades industriais, Gallais (2002) apresentou as noções de distância estrutural, distância ecológica e distância afetiva. Estas três noções poderiam ser aplicadas ao exame das distâncias percebidas entre habitantes de Cachoeira e das demais vilas, entre várzea e da terra-firme, entre áreas rurais do Marajó oriental, entre campo, Marajó oriental e a mata, Marajó ocidental, entre diferentes áreas do Marajó e a cidade de Belém. Todavia, a nossa opção teórica foi o distanciamento entre mentalidades, influenciadas logicamente por distanciamentos estruturais, ecológicos e afetivos, onde elas fossem identificadas.

Para melhor distinguir as peculiaridades da sociedade ou de grupos ou subgrupos sociais, as distâncias e os espaços vividos interiorano-rural no Marajó é preciso que se tenha em mente que o espaço padrão de referência das áreas rurais ou dos interiores paraenses até as primeiras décadas do século XX, era o da pequena sociedade de corte provincial sediada em Belém. A vila/povoado de Cachoeira era um importante elemento do espaço vivido, lugar das trocas comerciais, de maiores facilidades de deslocamentos para Belém, das relações entre indivíduos de grupos ou subgrupos sociais diferentes que percebiam e idealizava de formas similares, num certo sentido, a vida cultural e a sociedade de corte de Belém.

\section{CONSIDERAÇÕES FINAIS}

A ambição dos indivíduos, particularmente, dos pobres ou dos socialmente marginalizados de ascender socialmente quer por casamento com ricos (comerciantes, banqueiros ou donos de terras, geralmente, sediados nas cidades) ou com profissionais liberais bem sucedidos, ou políticos ricos, quer por educação ou por emprego, era tão antiga, quanto os contrastes entre o interior-rural (Marajó) e a cidade-capital (Belém), sede da pequena corte provincial ou centro do poder financeiro e políticoadministrativo. 
Ambos (o interior ou o rural) foram tradicionalmente objetos de descrição na literatura regionalista, particularmente até a primeira metade do século XX, quando o Brasil e a Amazônia eram predominantemente rurais. As representações do interior-rural e da cidade de Belém na Amazônia paraense não eram diferentes do que era encontrado nos interiores e capitais no restante do País.

Escolhemos trabalhar com Dalcídio Jurandir, autor ficionista e ensaísta, pela importância que este autor atribuiu às representações do interior-rural e da cidade-capital do Pará, tanto quando trabalhou o Marajó, quanto escreveu sobre Belém. Jurandir, por meio de seus personagens, descreveu, portanto, uma multiplidade de visões acerca do interior dominantemente rural e da cidade em momentos diversos atribuindo-lhes pesos ou valores diversos. Enquanto as cidades - em especial a cidade de Belém - projetavam e ainda projetam para fora imagens fantasiosas repletas da visão de progresso ou do moderno trabalho assalariado, o interior-rural guardava e guarda, de certa maneira, imagens de rusticidade, de atraso, de incivilidade, cultivadas pelos citadinos de todas as classes sociais e etnias e, contemporaneamente, pelos turistas. Ou ainda, enquanto a cidade de Belém foi quase sempre uma miragem para a maioria dos moradores de Cachoeira, portadores de imagens fruto de uma ingenuidade utópica urbana, a imagem do rural decadente, triste e sem esperança de mudanças apresentavam-se nos campos do concreto e do subjetivo para estes personagens citadinos e interioranos ou rurais do escritor marajoara. Assim, Jurandir observou também as tensões psicológicas dos habitantes do interior e mais tarde dos habitantes da cidade.

Como explicar as atrações que a cidade, sobretudo a capital Belém, continua ainda a exercer sobre o rural e como compreender os efeitos disto nas continuidades, de certa forma, das representações sociais dos interiores da ilha (Marajó) - e das cidades locais, ou particularmente da cidade-capital do estado do Pará, de forma, ainda, a conferir atualidade à leitura das obras de Dalcídio Jurandir? Tais explicações podem vincular-se em grande parte (mas não só) aos fatos de que os indivíduos milenarmente alimentaram e alimentam suas disposições de mudar o destino social e o status econômico, progetando nas cidades o "paraíso" mágico que pode tornar as oportunidades sociais mais possíveis de serem realizadas para o bem ou para o mal.

Contemporaneamente, as mudanças nos contrastes entre os interiores-rurais e as cidades de portes variados no contexto brasileiro e, mesmo, amazônico têm sido marcantes, em face dos avanços nos meios de comunicações. $\mathrm{O}$ desemprego crescente que atinge os membros qualificados e nãoqualifica dos das camadas médias e as maiorias sociais empobrecidas e ameaçadas pela miséria fazemcom que a cidade perca os seus encantos. Os "bandoleiros", os famintos revoltosos provenientes do meio-rural, que ocupavam as periferias das cidades, formando cinturões de pobreza nas cidades em torno das cidades do Marajó e da cidade de Belém, assim as classes médias e as elites nas cidades se sentiam ameaçadas por possíveis revoltas ou levantes (insurreções) sociais, por parte daqueles para quem as chances de saídas individualizadas de ascensão social e econômica eram e são muito remotas.

Tentando ser, como os demais romancistas regionalistas (e não há aqui nenhum sentido depreciativo, muito pelo contrário, acreditamos que são os bons regionalistas que tendem a si tornarem escritores universalistas), ou cronistas, fiéis a sua época (ou ao tempo retratado) e à realidade vivida ou imaginada, Dalcídio tendeu a ser quase sempre um revelador de velhos mitos, imagens e visões (representações), entremeando realidades subjetivas com registros literários, mais do que histórico geográficos de sua época. Particularmente, na obra Chove nos Campos de Cachoeira (finalizada em 1939 e lançada pela Vecchi Editora, em 1941) Dalcídio Jurandir contribuiu, talvez de forma inconsciente, graças às ambigüidades de seus personagens no Marajó ou em Belém, para reforçar, de um lado, os mitos como "solidão" ou "isolamento" campestre, e de outro, os mitos de isolamento ou de distanciamento da cidade de Belém (próxima e, ao mesmo tempo, distante de Marajó) como centro da interação, ou da convivência "civilizada", 
centro administrativo, religioso, educacional e cultural, além de comercial, estruturador dos interiores.

A estruturação que guiou a sua narrrativa foi a lógica das representações, dos contrastes entre áreas geográficas distintas e relativamente distantes (porém, fisicamente não tão distantes), ou mesmo próximas, no entanto, separadas pela "mitos" ou "realidades" de ausência de dinamismo social e econômico, de abandono ou ainda pela visão de progresso urbano que constratava com a imagem de miséria da cidade. Em outras palavras, o que o autor tinha em mente, talvez era, a crítica à centralização de Belém, à ruralidade do Marajó e à visão do interior e da cidade como local de fantasias provincianas, de bem-estar e, ao mesmo tempo, de mal-estar causado pelas mazelas reveladas por meio das incursões de Alberto no espaço rural ou urbano. Ou ainda, o autor por meio de Alberto recheiou os dois (o interior ainda dominante rural e a cidade) com os dramas e as misérias humanas.

Em nossa concepção, tanto o interior-rural (ou o campo) quando o urbano eram e são espaços sociais, histórico-geográficos e mentalmente construídos. No passado, um se distinguia do outro pela singularidade das atividades exercidas, pelas condições e modos de vida social (rústica ou civilizada) que se levava em cada um, em virtude da proximidade física ou do relativo isolamento (geográfico e cultural) e da forte, fraca ou nula mobilidade (econômica e social) dos habitantes do rural e dos graus de concentração ou dispersão das populações. Todavia, com o avanço capitalista acompanhado do processo de rápida urbanização, o rural não mais se diferencia do urbano pelas formas de uso do solo, e cada vez menos se distingue do urbano pelo estilo ou modo de vida, pela expansão no rural de atividades tidas anteriormente como exclusivamente urbanas, pela mobilidade geográfica da população e da produção, pela incorporação de valores e hábitos "modernos" ou "civilizados" oriundos da cidade pelos habitantes do interior-rural. Daí a criação de novas categorias como "populações tradicionais", "os favelados da cidade", "os sem-teto" para se referir, no primeiro caso, às populações com relações específicas ou mais dependentes da natureza (dos recursos naturais), e nos segundo e terceiro casos, às populações dotadas ou não de condições materiais e imateriais mínimas de vida, imunes, muitas vezes, às influências dos centros desenvolvidos e equipados das cidades, onde vivem.

Sem reduzir a importância dos registros histórico-geográficos ou literários de um autor específico, é preciso não deixar de reconhecer: i) os limites de uma obra literária (representação linguística de um autor singular) na contextualização e na composição de um retrato de uma região e das relações entre o interior-rural e o urbano ou das relações intra-rurais e intra-urbanas; ii) as tensões entre o concreto, o objetivo e as percepções subjetivas presentes nas narrativas; iii) a especificidade da linguaguem literária que ora suaviza ora exagera as realidades (interioranas-rurais ou urbanas) descritas, fazendo-as parte de realidades idealizadas diversas. Não são a cidade ou o rural que fascinam os leitores de Dalcídio, mas as estórias dos indivíduos de posições sociais diversas que estavam naqueles lugares (Cachoeira no Marajó ou Belém), num momento particular da história. Por último, a cidade de Cachoeira no Marajó, e mais particularmente, a cidade de Belém passaram por modificações radicais a partir, sobretudo, da segunda metade do século XX, o que acentua ainda mais o peso histórico dos registros "realísticos" e o valor das criações literárias que compuseram as obras de Dalcídio Jurandir.

Para finalizar, ressaltaríamos a importância para sociólogos, historiadores e geógrafos de identificar aspectos físicos e sociais, de reconhecer personagens próprios da realidade social e econômica de áreas geográficas e tempos específicos, conhecer metalidades, modos e costumes da sociedade, geográfica e historicamente situadas, de examinar mitos, imagens e estereótipos, suas hierarquizações e articulações no conjunto das obras literárias utilizadas como fontes essenciais ao enriquecimento da sensibilidade sócio-regional dos analistas sociais. Por tudo isto, Dalcídio Jurandir é antes de tudo um autor significativo e fundamental à compreensão da Amazônia oriental de um momento histórico particular, isto é, sua 
obra contém contribuições sobre o entendimento dos aspectos e problemas da vida social quotidiana no Marajó e em Belém, numa época transitória, pósescravista, pós-monarquismo e pós-império da borracha, após a primeira década do século XX. A leitura das obras de Dalcídio Jurandir continua instigante e indispensável aos pesquisadores contemporâneos da Amazônia oriental, cujo eixo de desenvolvimento mudou radicamente para áreas abertas pela Belém-Brasília na década de 1960, num contexto que previa o desenvolvimento pastoril de Paragominas, estimulado pelo esquema Superintendência do Desenvolvimento da Amazônia - Banco da Amazônia S. A. (SUDAM/BASA), como alternativa de expansão para os pecuaristas de dentro (do Marajó) e de fora, da região amazônica. Todavia, esta redefinição de eixo do povoamento e de desenvolvimento dos rios para as estradas contribuíu ainda mais para reforçar as idéias ou mitos de isolamento e de distanciamento, pelo menos, econômico do Marajó em relação a Belém e demais cidades-centros regionais do estado do Pará.

\section{NOTAS}

(1) O barco era o único meio de acesso à Belém, até a primeira metade do século XX.

(2) O conceito de elite está aqui empregado para se referir a uma parcela minoritária de uma determinada sociedade, composta de indivíduos com prestígio social e com poder.

(3) Evitaremos sempre que for possível o uso do termo "campo" que será quase sempre substituído pelo rural, ou o interior-rural, de forma a não confundir o leitor com o bioma campos naturais que domina a porção oriental de Marajó. Para o autor analisado, o Marajó de sua época representa um interior de estrutura fundiária há muito consolidada e que contava só com algumas poucas vilas, ainda embriões de cidade como fica mais claro no quadro 1 apresentado neste texto.

(4)

(5) Este termo foi usado pelo Dalcídio e parece se referir aos tios negros (do lado materno) de Alfredo, indivíduos mulatos tidos como relativamente livres e, por isso mesmo, como "moles", malandros, ociosos, que pulavam de emprego para emprego, sem se fixarem, eram ou não, namoradores, amantes da música, das festas e das bebidas.

(6) Por classes sociais ou camadas sociais entendemos aqui formas de agregações de indivíduos (com mesmos interesses ou visões de mundo), pertencentes a um meio social específico ou a uma determinada categoria social, vinculadas a laços sociais comuns, aos papéis desempenhados característicos e às mesmas posições sociais, numa sociedade desigual e hierárquica.

(7) Por grupos étnicos reuniões de indivíduos pertencentes a uma determinada origem étnica que lhes confere traços identitários comuns.

\section{REFERÊNCIAS BIBLIOGRÁFICAS}

ACEVEDO R. E. M. Tableaux de uma sociedade pós-escravista. In: Leite, M. (Org.) Leituras Dalcidianas. Belém: UNAMA, 2006. p. 93-112.

BOLLE, Willi. Fisiognomia da Metrópole Moderna. Representação Histórica em Walter Benjamin. São Paulo: Editora da Universidade de São Paulo, 1994.

BOURDIEU, P. O poder simbólico. Lisboa: DIFEL, 1989.

CANDIDO, Antônio. Os Parceiros do Rio Bonito. São Paulo: Editora 34, 1997 (8 Edição).

CARNEIRO, M. J. T. Ruralidades: novas identidades em construção. Estudos - Sociedade e Agricultura. Rio de Janeiro, n. 11, out., 1998. p. 7-14. 
DERRUAU, Max. Geografia Humana II. Lisboa: Presença; Rio de Janeiro: Martins Fontes, 2 v. Revista da ANPEGE. v. 3, 1973. p. $57-86,2007$

DAOU, A. M. A belle époque amazônica. Rio de Janeiro: Jorge Zahar, 2000.

ELIAS, Norbert. A Sociedade de Corte. Rio de Janeiro: Jorge Zahar, 2001.

JURANDIR. Três casas e um Rio. 3 ed. Belém: CEJUP, 1994.

Chove nos Campos de Cachoeira. Rosa Assis organizadora Belém: UNAMA, 1998.

D. Belém do Grão Pará. 2 ed. Belém: EDUFPA; Rio de Janeiro: FCRB, 2004.

FERREIRA, J. C. V. O Pará e seus Municípios. Belém: Rede, Empresas de Energia Elétrica - Celpa, 2003.

GALLAIS, Jean. Alguns Aspectos do Espaço Vivido nas Civilizaçõesdo Mundo. (publicado originalmente como Quelques aspects de l'espace vécu dans les civilizations du monde tropical. L’Espace Géographique, 5 (1), 1976). In: Corrêa, R. L e Rosendahl, Z. Geografia Cultural: Um Século(3). Rio de Janeiro:UERJ, 2002. pp. 63-81.

GRUPO RETIS. Proposta de Reestruturação do Programa de Desenvolvimento da Faixa de Fronteira. Brasília: Ministério da Integração Nacional, 2005.

HAESBAERT, R. Territórios Alternativos. São Paulo: Contexto Acadêmica EdUFF, 2002.

LEITE, M. (org.). Leituras Dalcidianas. Belém: UNAMA, 2006.

Cenas da vida Amazônica: ensaio sobre a narrativa de Inglês de Sousa. Belém: UNAMA, 2002.

. A dialética da "matutice" e da "civilidade". Revista Trilhas, Belém, v. 1, n. 2, 2000. p. 48-55, nov.

LIMA, E. N. O exótico nas narrativas sobre a Amazônia. In: SILVA, F. C. T. da.; SANTOS, R.; COSTA, L. F. de C. (1998). Mundo rural e política. Rio de Janeiro: Campus, 1998. p. 61-74.

MALIGO, P. Ruínas idílicas: a realidade amazônica de Dalcídio Jurandir. Revista USP, São Paulo,13, 1992. p. 48-57.

MIRANDA NETO, M. J. de. A Foz do Rio-Mar. Rio de Janeiro: Record, 1968.

QUEDA, Oriowaldo (orgs.). Vida Rural e Mudança Social (leitura básica de sociologia rural). 3 ed. São Paulo: Cia. Editora Nacional, 1979. p. 160-176.

QUEIROZ, M. Isaura Pereira de. Do rural e do urbano no Brasil. In: SZMRECSÁNYI, Tamás, 1979.

. Dialética do rural e do urbano: exemplos brasileiros. In: . Cultura, Sociedade Rural, Sociedade

Urbana no Brasil. Rio de Janeiro: LTC; São Paulo: EDUSP, 1978. p. 263-314.

SALLES, Vicente. Chão de Dalcídio. In: JURANDIR, Dalcídio. Marajó. 3. ed. Belém: CEJUP, 1992. p. 367-381.

SARGES, M. de N. Belém: Riquezas Produzindo a Belle-Époque (1870-1912). Belém: Paca - Tatu, 2000.

SPOSITO, M. E. B.; WHITACKER, A. M. (Orgs.) Cidade e campo: relações entre urbano e Rural. São Paulo: Expressão Popular, 2006.

VIEIRA BARROSO A. E. Marajó. Rio de Janeiro: Ministério Biblioteca do Exercito, Vol. 197, 1954.

WILliAMS, Raymond. O Campo e Cidade; na história e na literatura. São Paulo: Cia. das Letras, 1990.

Recebido em maio de 2007

Aceito em agosto de 2007 